không phát hiện được nguyên nhân nào khác. Diễn biến lâm sàng dần ổn định khi điều trị tình trạng cường giáp, huyết áp bệnh nhân trở về bình thường khi bệnh nhân đạt trạng thái cường giáp $(110 / 60 \mathrm{mmHg})$. Do đó, khi tiếp cận bệnh nhân tăng huyết áp cần kiểm tra chức nắng tuyến giáp của bệnh nhân.

Điều trị bằng hormon kháng giáp là cần thiết nhằm cân bằng lại chuyển hóa và giúp bệnh nhân trở lại trạng thái bình giáp. Liều điều trị trung bình của bệnh nhân là $0,59 \mathrm{mg} / \mathrm{kg} / \mathrm{ngày}$. Bên cạnh đó, thuốc chẹn thụ thể beta giúp điều hòa nhịp tim, dùng khi mạch của bệnh nhân > 90 lần/phút (mạch khi ngủ). Theo dõi cẩn thận chức năng tuyến giáp, nồng độ kháng thể kháng tuyến giáp trong máu là rất quan trọng để xác định tình trạng cường giáp của bệnh nhân cả về mặt đáp ứng điều trị, giai đoạn suy giáp cũng như tái phát của bệnh.

\section{KẾT LUÂN}

Bướu cổ là triệu chứng hay gặp nhất bên cạnh những biểu hiện cường giáp điển hình đi kèm khiến trẻ đến khám trong bệnh cường giáp do viêm tuyến giáp Hashimoto. Xét nghiệm kháng thể kháng giáp giúp chẩn đoán và tiên lượng bệnh. Xét nghiệm chức năng tuyến giáp để chẩn đoán, theo dõi và điều trị. Phát hiện sớm và điều trị kịp thời nhằm hạn chế ảnh hưởng đến phát triển thể chất, tẩm thần và phòng tránh biến chứng. Điều trị bằng thuốc kháng giáp trạng. Tiếp cận bệnh nhân cường giáp cần tìm nguyên nhân giúp cho quá trình theo dõi, điều trị và tiên lượng bệnh.

VIẾT TẮT. T3: Triidothyronine

FT4: Free Thyoxin
TSH: Hormon kích thích tuyến giáp

Anti - Tg: Anti Thyroglobulin

Anti - TPO: Anti Thyroid Peroxidase

TRAb: TSH receptor antibodies

\section{TÀI LIỆU THAM KHẢO}

1. Caturegli P., De Remigis A., Rose N.R. (2014). Hashimoto thyroiditis: Clinical and diagnostic criteria. Autoimmunity Reviews,13(4), 391-397.

2. Wasniewska M., Vigone M.C., Cappa M. et al. (2007). Acute suppurative thyroiditis in childhood: relative frequency among thyroid inflammatory diseases. J Endocrinol Invest, 30(4), 346-347.

3. Takasu N., Yamada T., Sato A. et al. (1990). Graves' Disease Following Hypothyroidism Due To Hashimoto's Disease: Studies Of Eight Cases. Clinical Endocrinology, 33(6), 687-698.

4. Radetti G., Gottardi E., Bona G. et al. (2006). The natural history of euthyroid Hashimoto's thyroiditis in children. The Journal of Pediatrics, 149(6), 827-832.

5. Wasniewska M., Wasniewska M., Corrias A. et al. (2012). Outcomes of Children with Hashitoxicosis. HRP, 77(1), 36-40.

6. McGrogan A., Seaman H.E., Wright J.W. et al. (2008). The incidence of autoimmune thyroid disease: a systematic review of the literature. Clinical Endocrinology, 69(5), 687-696.

7. Jaruratanasirikul ' $S_{\text {., }}$ 'Leethanaporn $K_{\text {., }}$ Khuntigij P. et al. (2011). The Clinical Course of Hashimoto's Thyroiditis in Children and Adolescents: 6 Years Longitudinal Follow-up. Journal of Pediatric Endocrinology and Metabolism, 14(2), 177-184.

8. Dittmar M., Libich C., Brenzel T. et al. (2011). Increased familial clustering of autoimmune thyroid diseases. Horm Metab Res, 43(3), 200-204.

9. Marazuela M., García-López M.A., FigueroaVega N. et al. (2006). Regulatory $T$ Cells in Human Autoimmune Thyroid Disease. J Clin Endocrinol Metab, 91(9), 3639-3646.

\title{
ĐẶC ĐIỂM LÂM SÀNG, CÂ̂N LÂM SÀNG NGộ ĐộC CẤP METHANOL
}

\section{TÓM TẮT}

Mục tiêu: Nhận xét đặc điểm lâm sàng, cận lâm sàng ngộ độc cấp methanol. Đối tượng và phương pháp: Nghiền cứu mô tả trên 107 bệnh nhân ngộ độc cấp methanol điều trị tại Trung tâm chống độc bệnh

*Trung Tâm Chống Độc - Bệnh viện Bạch Mai Chịu trách nhiệm chính: Đặng Thị Xuân Email: xuandangthi17@gmail.com Ngày nhận bài: 25.12.2020

Ngày phản biên khoa học: 11.2.2021

Ngày duyệt bài: 23.2.2021
Đặng Thị Xuân*

viện Bạch Mai từ 01/2016 đến 07/2019. Kết quả: Bểnh nhân nam $(97,2 \%)$; tuổi trung bình là 47,6 \pm 12,6 ; tỉ lệ tử vong cao $(41,1 \%)$. Đặc điểm lâm sàng: đau đầu và nhìn mờ gặp nhiêuu nhất $(94,4 \%)$, hôn mê sâu $(63,6 \%)$, giãn đồng tử $(61,7 \%)$, mất phản xạ ánh sáng $(45,8 \%)$, suy hô hấp $(79,4 \%)$, suy thân cấp $(54,2 \%)$, tụt huyết áp $(31,8 \%)$, co giật gặp ít nhất $(6,5 \%)$. Nhóm BN tử vong gặp ở tỉ lệ cao hơn nhóm sống. Đặc điểm cận lâm sàng: toan chuyển hóa nặng, ALTT, KT ALTT, KT anion, CK, lactat, đường máu đều cao, các chỉ số của nhóm tử vong cao hơn nhóm sống $(p<0,05-p<0,01)$. Nồng độ methanol máu cao $157,1 \pm 90,06 \mathrm{mg} / \mathrm{dL}$, nhóm tử vong cao hơn nhóm 
sống, $\mathrm{p}<0,01)$. Tổn thương thần kinh trên $\mathrm{CT} / \mathrm{MRI}$ so $63,4 \%$ (giảm tỷ trọng nhân bèo $42,3 \%$, xuất huyết não nhân bèo $8,5 \%$, tổn thương chất trắng dưới vỏ $8,5 \%$, phù não $4,23 \%$ ). Tổn thương mắt $62,9 \%$ (tổn thương thị thần kinh $37,2 \%$; phù gai thị $21,4 \%$; xuất huyết võng mac 4,3\%). Kết luận: Ngộ độc methanol có các đặc điểm và dấu hiệu nặng của nhiều cơ quan, tỉ lệ tử vong cao.

Tư khóa: ngộ độc cấp, methanol.

\section{SUMMARY}

\section{CLINICAL FEATURES AND LABORATORY CHARACTERISTICS OF PATIENTS WITH ACUTE METHANOL POISONING}

Objective: to assess clinical characteristics and laboratory abnormalities of patients with acute methanol poisoning. Subjects and Methods: A observational study included 107 methanol poisoned patients treated at Poison Control Center of Bach Mai Hospital from January 2016 to July 2019. Results: The study patients were mainly male $(97.2 \%)$, the mean age were $47.6 \pm 12.6$ years old. The mortality was high $(41.1 \%)$. Clinical features: headache and blurred vision most frequently encountered (94.4\%), the were deep comma $(63.6 \%)$, dilated pupils $(61.7 \%)$, loss of light reflection $(45.8 \%)$, respiratory failure $(79.4 \%)$, acute renal failure $(54.2 \%)$, hypotension $(31.8 \%)$. Seizures were not common $(6.5 \%)$. The rates of severe symtomps was higher in the fatal group. Laboratory features: severe metabolic acidosis, OG, AG, CK, lactate, blood glucose were all high, and the indicators of the mortality group were much higher. Methanol concentration was high (157.1 $\pm 90.06 \mathrm{mg} / \mathrm{Dl}$ ). Neurological damages on CT/MRI were $63.4 \%$. Eye damage $62.9 \%$ (vision damage $37.1 \%$; papillary edema $21.4 \%$; retinal hemorrhage 4.3\%). Conlusion: Methanol poisoning had the characteristics and signs of severe multiple organs failures, high mortality.

Keywords; acute poisoning, methanol.

\section{I. ĐĂT VẤN ĐỀ}

Methanol hay còn gọi là methyl alcohol hay alcol methylic, được phát hiện tình cờ khi thủy phân gỗ, ngày nay được sản xuất kiểu công nghiệp bằng các phản ứng hóa học. Methanol được sử dụng rộng rãi trong nhiêu ngành công nghiệp nhưng rất độc nên không được dùng làm rượu thực phẩm. Ngộ độc methanol có thể qua đường hô hấp, qua da, nhưng thường gặp nhất là qua đường tiêu hóa.

Ngộ độc methanol gặp ở nhiều nơi trên thế giới, nhiều vụ ngộ độc với số lượng lớn nạn nhân với tỉ lệ tử vong còn cao. Ở Việt Nam, ngộ độc methanol có xu hướng ngày càng tăng, theo Bộ $Y$ tế hàng năm có khoảng trên 1000 ca ngộ độc methanol. Tại Trung tâm chống độc Bệnh viện Bạch Mai, theo nghiên cứu của Phạm Như Quỳnh từ 2016 đến 2017 có 37 BN ngộ độc methanol, tỉ lệ tử vong lên đến $35,2 \%$ và di chứng là 37,8\% [1]. Việc đánh giá các đặc điểm của ngộ độc methanol giúp xác định các dấu hiệu nặng, các di chứng thần kinh và tổn thương mắt có vai trò quan trọng trong giảm tỉ lệ di chứng và tử vong cho bệnh nhân. Trên thế giới có một số nghiên cứu về đặc điểm và tiên lượng của bệnh nhân ngộ độc methanol. Ở Việt Nam còn ít nghiên cứu về đặc điểm và diễn biến của ngộ độc cấp methanol, do vậy chúng tôi tiến hành nghiên cứu nhằm mục tiêu "Nhận xét đặc điểm lâm sàng, cận lâm sàng ngồ độc cấp methanol" ở bệnh nhân ngộ độc cấp methanol tại Trung tâm chống độc bệnh viện Bạch Mai.

\section{II. ĐỐI TƯợNG VÀ PHƯƠNG PHÁP NGHIÊN CỨU}

2.1. Đối tượng nghiên cứu: Bệnh nhân ngộ độc cấp methanol điều trị tại Trung tâm Chống độc bệnh viện Bạch Mai từ tháng 1/2016 đến $7 / 2019$.

\section{Tiêu chuẩn chọn bệnh nhân}

- Bệnh sử có uổng rượu hoặc hóa chất nghi ngờ có methanol.

- Định lượng có methanol trong máu.

\section{Tiêu chuẩn loai trừ}

- Ngộ độc phổi hợp với chất khác (ngoài ethanol): thuốc ngủ, hóa chất bảo vệ thực vật..

- Tiền sử bệnh có di chứng thần kinh trung ương và di chứng thần kinh thị giác từ trước

\subsection{Phương pháp nghiên cứu}

Thiết kế nghiên cứu: Nghiên cứu mô tả

Phương pháp chọn mẫu: chọn mẫu toàn bộ

Nội dung và tiến hành nghiên cứu: bệnh nhân đủ tiêu chuẩn lựa chon được tiến hành thu thập số liệu theo mẫu bệnh án thống nhất:

- Các thông tin hành chính: Họ tên, tuổi, giới, địa chỉ, nghề nghiệp

- Tiền sử bệnh, nguyên nhân ngộ độc, loại đồ uống gây ngộ độc, thời gian từ khi ngộ độc đến khi vào viện, chẩn đoán và xử trí trước khi vào viện

- Triệu chứng lâm sàng:

+ Thẩn kinh: Đau đầu, chóng mặt, hôn mê, co giật, phản xạ gân xương

+ Thị giác: Nhìn mờ, giảm thị lực, mất thị lực, đồng tử giãn, mất phản xạ ánh sáng.

+ Hô hấp: nhịp thở, $\mathrm{SpO} 2$, suy hô hấp, nhịp thở, ran ở phổi, viêm phổi sặc.

+ Tuần hoàn: mạch, huyết áp, tụt huyết áp

+ Thận, tiết niệu: số lượng nước tiểu: tiểu ít, vô niệu. vân...

+Các triệu chứng khác: tiêu hóa, tiêu cơ

- Cân lâm sàng:

+ Cồng thức máu, đông máu cơ bản 
+ Hóa sinh máu: ure, creatinin, glucose, CK, AST, ALT, bilirubin, điện giải đồ, lactat máu. Nước tiểu: tổng phân tích nước tiểu.

+ Khí máu, áp lực thẩm thấu (ALTT) máu, khoảng trống (KT) ALTT, khoảng trống anion

+ Định lượng methanol và ethanol máu bằng sắc kí khí tại viện Giám định Pháp Y.

+ Soi đáy mắt đánh giá tổn thương thị thần kinh, gai thị, võng mạc

+CT/MRI sọ: đánh giá tổn thương nhân bèo, xuất huyết não, thoái hóa chất trắng, phù não

- Điều trị:

+ Hồi sức chung: thở oxy, thở máy, truyền dịch, truyền bicarbonat, thuốc vận mạch...

+ Điều trị giải độc đặc hiệu (ethanol 20\% đường uống), acid folinic, lọc máu

- Kết quả điều trị: khỏi, di chứng, tử vong, di chứng.

Phương tiện nghiên cứu: Các xét nghiệm được làm tại khoa Huyết học, Hóa sinh, Xquang, thăm dò chức nặng của bênh viện Bach Mai.

2.3. Xử lí số liệu. Số liệu được xử lý theo phương pháp thống kê y học, sử dụng phần mềm SPSS 20.0. So sánh giá trị 2 trung bình bằng Student test (Mann-Witney $U$ test nếu phân bố không chuẩn), so sánh tỉ lệ \% bằng test $X 2$ hoặc Fisher Exact test, mức ý nghĩa thống kê 95\%.

\section{KẾT QUẢ NGHIÊN CỨU}

Trong thời gian từ 01/2016-07/2019, có 107 bệnh nhân đủ tiêu chuẩn chọn vào nghiên cứu.
Một số kết quả thu được như sau:

3.1. Đặc điểm chung của bệnh nhân nghiên cứu

Phân bố theo giới: Bênh nhân nam là chủ yếu 104/107 BN (97,2\%); Nữ 3/107 BN (2,8\%). Tỉ lệ giới Nam/nữ là 34,7:1

Phân bố theo tuổi: Tuổi trung bình của bệnh nhân nghiên cứu là $47,6 \pm 12,6$ tuổi (1672). Bệnh nhân chủ yếu ở nhóm tuổi trung niên 40-59 tuổi $(65,4 \%)$.

- Kết quả điêuu trị:

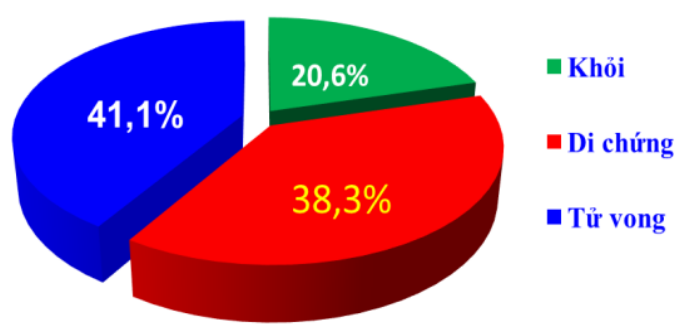

Biểu đồ 3.1. Kêt quả điều trị

Nhận xét: Tử vong 44 BN (41,1\%); sống 63 BN (58,9\%). Trong 63 BN sống, có 22 BN sống không di chứng $(20,6 \%)$ còn $41 \mathrm{BN}$ có di chứng $(38,3 \%)$.

3.2. Đặc điểm lâm sàng, cận lâm sàng và điêu trị của bệnh nhân ngộ độc methanol

\subsection{1. Đặc điểm lâm sàng}

Bảng 3.1. Triệu chứng lâm sàng thường gặp lúc vào viện

\begin{tabular}{|c|c|c|c|c|c|c|c|}
\hline Nhóm & \multicolumn{2}{|c|}{ Tống BN $(n=107)$} & \multicolumn{2}{|c|}{ Sống $(n=63)$} & \multicolumn{2}{|c|}{ Tứ vong $(n=44)^{(2)}$} & P (1) và (2) \\
\hline Chỉ số & $\mathbf{n}$ & $\%$ & $\mathbf{n}$ & $\%$ & $\mathbf{n}$ & $\%$ & \\
\hline Đau đâu & 101 & 94,4 & 58 & 92,1 & 43 & 97,7 & $>0,05$ \\
\hline Nhìn mờ & 101 & 94,4 & 57 & 90,5 & 44 & 100,0 & $>0,05$ \\
\hline Suy hô hấp cấp & 85 & 79,4 & 41 & 65,1 & 44 & 100,0 & $<0,01$ \\
\hline Glasgow $<8$ điểm & 68 & 63,6 & 24 & 38,1 & 44 & 100,0 & $<0,01$ \\
\hline Đồng tử giãn & 66 & 61,7 & 24 & 30,1 & 42 & 95,5 & $<0,01$ \\
\hline Mất phản xạ ánh sáng & 49 & 45,8 & 12 & 19,1 & 37 & 84,1 & $<0,01$ \\
\hline Suy thận cấp & 58 & 54,2 & 20 & 31,8 & 38 & 86,4 & $<0,05$ \\
\hline Tụt huyết áp & 34 & 31,8 & 2 & 3,2 & 32 & 72,7 & $<0,01$ \\
\hline Co giật & 7 & 6,5 & 1 & 1,5 & 6 & 13,6 & $<0,05$ \\
\hline
\end{tabular}

Nhận xét: Triệu chứng đau đầu và nhìn mờ gặp nhiều nhất $(94,4 \%)$, hôn mê sâu $(63,6 \%)$, giãn đồng tử $(61,7 \%)$, suy thận cấp $(54,2 \%)$, mất phản xạ ánh sáng $(45,8 \%)$, suy hô hấp $(79,4 \%)$, tụt huyết áp (31,8\%), co giật gặp ít nhất (6,5\%).

Nhóm BN tử vong gặp ở tỉ lệ cao hơn nhóm sống về: hôn mê sâu, đồng tử giãn, mất phản xạ ánh sáng, co giật, suy hô hẩp, suy thận cấp và tụt huyết áp $(p<0,05-p<0,01)$.

3.1.2. Đặc điểm cận lâm sàng của bệnh nhân ngộ độc methanol

Bảng 3.2. Một số xét nghiệm máu lúc vào viện

\begin{tabular}{|c|c|c|c|}
\hline Chỉ số $\quad$ Nhóm & Sống $(n=63)^{(1)}$ & Tử vong $(n=44)^{(2)}$ & $p^{(1) ~ v a ̀ ~(2) ~}$ \\
\hline $\mathrm{pH}$ & $7,09 \pm 0,19$ & $6,85 \pm 0,13$ & $<0,01$ \\
\hline $\mathrm{pO}_{2} \quad(\mathrm{mmol} / \mathrm{l})$ & $159,2 \pm 85,49$ & $222,5 \pm 151,59$ & $>0,05$ \\
\hline
\end{tabular}




\begin{tabular}{|c|c|c|c|}
\hline $\mathrm{pCO}_{2}(\mathrm{mmol} / \mathrm{l})$ & $20,4 \pm 9,35$ & $41,5 \pm 79,73$ & $>0,05$ \\
\hline $\mathrm{HCO}_{3}(\mathrm{mmol} / \mathrm{l})$ & 6,7 & 3,3 & $>0,05 *$ \\
\hline Áp lực thấm thấu (mosmol/kg H2O $)$ & $372,3 \pm 43,39$ & $413,0 \pm 33,84$ & $<\mathbf{0 , 0 1}$ \\
\hline Khoảng trống áp lực thấm thấu & $75,0 \pm 44,24$ & $96,0 \pm 40,43$ & $<\mathbf{0 , 0 5}$ \\
\hline Khoảng trống anion & $36,0 \pm 9,10$ & $49,0 \pm 19,24$ & $<\mathbf{0 , 0 5}$ \\
\hline Lactat (mmol/l) & $5,3 \pm 4,62$ & $9,6 \pm 4,91$ & $<\mathbf{0 1 0 1}$ \\
\hline Nồng độ methanol $(\mathrm{mg} / \mathrm{dL})$ & $131,2 \pm 82,01$ & $194,2 \pm 89,92$ & $<\mathbf{0 , 0 1}$ \\
\hline Nồng độ ethanol $(\mathrm{mg} / \mathrm{dL})$ & $12,1 \pm 35,98$ & $18,5 \pm 54,69$ & $>0,05$ \\
\hline CK (U/L) & 357,2 & 1885,4 & $<\mathbf{0 , 0 1 *}$ \\
\hline Bạch cầu $(\mathrm{G} / \mathrm{L})$ & $14,6 \pm 6,93$ & $14,3 \pm 8,86$ & $>0,05$ \\
\hline Hemoglobin $(\mathrm{g} / \mathrm{l})$ & $143,6 \pm 20,87$ & $132,8 \pm 18,37$ & $>0,05$ \\
\hline Hematocrit $(\%)$ & $0,43 \pm 0,072$ & $0,41 \pm 0,052$ & $>0,05$ \\
\hline Tiểu câuu $(\mathrm{G} / \mathrm{L})$ & $236,0 \pm 88,90$ & $208,3 \pm 87,25$ & $>0,05$ \\
\hline
\end{tabular}

(*Mann-Witney U test)

- Nồng độ methanol máu trung bình của tất cả BN là 157,1 \pm 90,06 mg/dL (20 - 399). Có 97BN $(91,7 \%)$ nồng độ methanol $\geq 50 \mathrm{mg} / \mathrm{dL}$

Nhận xét: Bệnh nhân vào viện trong tình trạng toan chuyển hóa nặng, ALTT cao, KT ALTT cao, $\mathrm{KT}$ anion cao, nồng độ methanol, $\mathrm{CK}$, lactat và đường máu đều cao, các chỉ số của nhóm tử vong đều cao hơn nhóm sống nhiều $(p<0,05-p<0,01)$.

Bảng 3.3. Đặc điểm tổn thương thần kinh trên CT/MRI ở bệnh nhân ngộ độc methanol

\begin{tabular}{|c|c|c|c|c|c|c|c|}
\hline Nhóm & \multicolumn{2}{|c|}{$\begin{array}{l}\text { Tống BN } \\
(n=107)\end{array}$} & \multicolumn{2}{|c|}{ Sống (n=63) } & \multicolumn{2}{|c|}{$\begin{array}{l}\text { Tử vong } \\
(n=44)\end{array}$} & $\mathbf{p}^{\text {(1) và (2) }}$ \\
\hline Tổn thương & $\mathbf{n}$ & $\%$ & $\mathbf{n}$ & $\%$ & $\mathbf{n}$ & $\%$ & \multirow{9}{*}{$>0,05$} \\
\hline Không chụp được & 36 & 33,3 & 4 & 3,7 & 32 & 29,6 & \\
\hline Có chụp & 71 & 66,4 & 59 & 55,2 & 12 & 11,2 & \\
\hline Bình thường & 26 & 36,6 & 26 & 36,6 & 0 & 0 & \\
\hline Tốn thương & 45 & 63,4 & 33 & 46,5 & 12 & 16,70 & \\
\hline $\begin{array}{l}\text { Giảm tỷ trơng nhân } \\
\text { bèo đối xứng } 2 \text { bên }\end{array}$ & 30 & 42,3 & 22 & 31,0 & 8 & 11,25 & \\
\hline Xuất huyết não & 6 & 8,5 & 5 & 7 & 1 & 1,45 & \\
\hline Tốn thương chất trăng & 6 & 8,5 & 6 & 8,45 & 0 & 0 & \\
\hline Phù não & 3 & 4,2 & 0 & 0 & 3 & 4,23 & \\
\hline
\end{tabular}

Nhận xét: - Có 71 BN được chụp, 36 BN (33,3\%) không chụp CT/MRI sọ vì BN nặng không thể đưa đi.

- Có tổn thương 45/71BN $(63,4 \%)$, trong đó giảm tỷ trọng nhân bèo đối xứng 2 bên gặp nhiều nhất $(42,3 \%)$, sau đó là xuất huyết não nhân bèo và tổn thương chất trắng dưới vỏ đều là $6 \mathrm{BN}$ $(8,5 \%)$, ít nhất là phù não $3 \mathrm{BN}(4,23 \%)$. Tỉ lệ tổn thương thần kinh ở $\mathrm{BN}$ sống và tử vong không khác nhau $(p>0,05)$.

Bảng 3.4. Đặc điểm tổn thương thị giác ở BN ngộ độc methanol

\begin{tabular}{|c|c|c|c|c|c|c|c|}
\hline Nhóm & & $\begin{array}{l}\text { BN } \\
\text { D7) }\end{array}$ & Sống & $63)^{(1)}$ & & $\begin{array}{l}n \\
\text { (2) } \\
\text { (2) }\end{array}$ & $\begin{array}{l}\mathbf{p}_{\text {(2) }}^{(1) ~ v a ̀ ~} \\
\text { (2) }\end{array}$ \\
\hline Tổn thương & $\mathbf{n}$ & $\%$ & $\mathbf{n}$ & $\%$ & $\mathbf{n}$ & $\%$ & \\
\hline Không khám & 37 & 34,6 & 8 & 7,5 & 29 & 27,1 & \\
\hline Có khám & 70 & 65,4 & 55 & 51,4 & 15 & 14,0 & \\
\hline Bình thường & 26 & 37,2 & 26 & 37,1 & 0 & 0 & $>0,05$ \\
\hline Có tốn thương & 44 & 62,9 & 29 & 41,4 & 15 & 21,4 & \\
\hline Tốn thương thị thần kinh & 26 & 37,2 & 20 & 28,6 & 6 & 8,6 & \\
\hline Phù gai thị & 15 & 21,4 & 8 & 11,4 & 7 & 10,0 & \\
\hline Xuất huyết võng mạc & 3 & 4,3 & 1 & 1,4 & 2 & 2,9 & \\
\hline
\end{tabular}

Nhận xét: - Có 37 BN (34,6\%) không được khám mắt do BN nặng, xin về sớm chưa kịp khám

- Có tổn thương mắt 44/70 (62,9\%): tổn thương thị thần kinh gặp nhiều nhất $26(37,1 \%)$, phù gai thị 15BN $(21,4 \%)$, xuất huyết võng mạc gặp ít nhất 3 BN $(4,3 \%)$. Không khác biệt giữa nhóm sống và tử vong $(p>0,05)$. 


\section{BÀN LUẬN \\ 4.1. Đặc điểm chung của bệnh nhân nghiên cứu}

- Phân bố về giới tính: Trong nghiên cứu, chúng tôi gặp chủ yếu là bệnh nhân nam 104BN $(97,2 \%)$ và chỉ có $3 B N$ nữ $(2,8 \%)$. Thực tế ở Việt Nam, nam uống rượu nhiều hơn nữ, nghiện rượu thường chỉ gặp ở nam giới. Chính vì vậy, ngộ độc methanol hay rượu nói chung cũng chủ yếu ở bệnh nhân nam. Nhận xét của chúng tôi cũng tương tự nghiên cứu của các tác giả Phạm Như Quỳnh nam giới là 96,67\% [1], của Lee C.Y. nam giới $87,5 \%$ [4].

- Phân bố về tuối: tuổi trung bình của các bệnh nhân là 47,6 \pm 12,6 tuổi, nhóm tuổi trung niên 40-59 tuổi chiếm tỉ lệ cao (65,4\%). Kết quả của chúng tôi tương tự nghiên cứu của Phạm Như Quỳnh, nhóm tuổi 50-59 chiếm 29,73\% [1]; nghiên cứu Lee C.Y. là 46,1 $\pm 13,8$ tuổi [4].

- Kết quả điều tri: Tỉ lệ tử vong trong nghiên cứu của chúng tôi là $44 / 107$ BN $(41,1 \%)$. Ngộ độc methanol là cấp cứu nặng, tỉ lệ tử vong cao vì các biến chứng nặng và các bệnh nhân thường tới muộn. Khi bệnh nhân uống rượu có cả methanol và ethanol, vì có chung enzym chuyển hóa là alcohol dehydrogenase ( $A D H)$, nhưng $\mathrm{ADH}$ lại có ái lực với ethanol gấp 7-10 lần so với methanol nên sẽ chuyển hóa ethanol trước, methanol được chuyển hóa chậm hơn nên các triệu chứng cũng xuất hiện muộn hơn. Kết quả của chúng tôi cao hơn nghiên cứu của Phạm Như Quỳnh (2017), tử vong 35,2\% [1]; của Lee C.Y. tử vong 34,4\% [4]; cao hơn nhiều với kết quả nghiên cứu của Wedge tử vong $8 \%$ [7]. Kết quả tử vong của chúng tôi cao hơn tác giả nước ngoài vì nhiều lý do như: nhiều người Việt hay uống rượu trôi nổi không rõ nguồn gốc hởn, tới viện chậm hơn, chưa thể xét nghiệm định lượng rượu ở tuyến trước được nên chẩn đoán chậm hơn, còn thiếu thuốc điều trị đặc hiệu như ethanol truyền tĩnh mạch, fomepizole. Vì vậy, muốn giảm tử vong và di chứng ở bệnh nhân ngộ độc methanol cần phối hợp nhiêu giải pháp: tuyên truyền giáo dục cho người dân hiểu rõ về tác hại của rượu độc, quản lý sản xuất và buôn bán rượu, nâng cao năng lực xét nghiệm và điều trị sớm ngay từ khi nghĩ tới ngộ độc methanol.

\section{2. Đặc điểm lâm sàng, cận lâm sàng và điêu trị của bệnh nhân ngộ độc methanol.}

4.2.1. Đăc điểm lâm sàng khi vào viện. Các bệnh nhân ngộ độc methanol vào viện với triệu chứng và dẩu hiệu nặng của nhiều cơ quan. Những triệu chứng thường gặp: đau đầu và nhìn mờ gặp nhiều nhất $(94,4 \%)$, hôn mê sâu $(63,6 \%)$, giãn đồng tử $(61,7 \%)$, suy thận cấp $(54,2 \%)$, mất phản xạ ánh sáng $(45,8 \%)$, suy hô hấp $(79,4 \%)$, tụt huyết áp $(31,8 \%)$, co giật gặp ít nhất (6,5\%). Nhóm BN tử vong gặp ở tỉ lệ cao hơn nhóm sống về: hôn mê sâu, đồng tử giãn, mất phản xạ ánh sáng, co giật, suy hô hấp, suy thận cấp và tụt huyết áp $(p<0,05$ $\mathrm{p}<0,01$ ).

Trong nghiên cứu của mình, tác giả Lee C.Y. cũng nêu một số đặc điểm lâm sàng của bệnh nhân ngộ độ̣c methanol tương đồng với nghiên cứu của chúng tôi như: suy thận cấp $(59,4 \%)$; glasgow trung bình $10,05 \pm 5,4$. Tuy nhiên, tỉ lệ suy hô hấp thấp hơn $(50 \%)$ và tụt huyết áp (50\%) cao hơn trong nghiên cứu của chúng tôi [4]. Sự khác nhau có thể do nhóm đối tượng không hoàn toàn giống nhau và số lượng bệnh nhân của chúng tôi là $107 \mathrm{BN}$ cao hơn của tác giả Lee là 32 bệnh nhân [4].

4.2.2. Đặc điểm cận lâm sàng khi vào viện. Nồng độ methanol máu trung bình trong nghiên cứu của chúng tôi rất cao: 157,1 \pm $90,06 \mathrm{mg} / \mathrm{dL}$ (20-399). Trong đó, có 10BN $(9,3 \%)$ nông độ methanol $<50 \mathrm{mg} / \mathrm{dL}$, còn $97 \mathrm{BN}$ $(91,7 \%)$ nồng độ methanol $\geq 50 \mathrm{mg} / \mathrm{dL}$. Tuy nhiên, nghiên cứu của tác giả Wedge (2012) nồng độ methanol máu trung bình là $73,6 \mathrm{mg} / \mathrm{dL}$, thấp hơn trong nghiên cứu của chúng tôi [7]. Theo các phác đồ đánh giá và tiên lượng các bệnh nhân ngộ độc methanol, nồng độ methnol máu $\geq 50 \mathrm{mg} / \mathrm{dL}$ là ngộ độc mức độ nặng, nhiều biến chứng, nguy cơ tử vong cao. Nhóm bệnh nhân tử vong của chúng tôi methanol máu lên tới 194,2 $\pm 89,92 \mathrm{mg} / \mathrm{dL}$. Nghiên cứu của tác giả Baceloux (2002) cũng đã đưa ra nhận định methanol máu $\geq 50 \mathrm{mg} / \mathrm{dL}$ là yếu tố tiên lượng tử vong [2].

Áp lực thẩm thấu máu trung bình lúc vào viện là $389,0 \pm 44 \mathrm{mOsmol} / \mathrm{kgH}_{2} \mathrm{O}(300-492)$. Khoảng trống ALTT máu là 83,6 $\pm 5,8$ (16-200). Khoảng trống anion là 40 (17-120). Tất cả các BN nhập viện đều tăng ALTT, KT ALTT, KT anion. Nhóm bệnh nhân tử vong tăng ALTT và KT ALTT, KT anion nhiêu hơn nhóm sống $(p<0,01)$. Tăng $A L T T$ và khoảng trống thẩm thấu gián tiếp phản ánh nồng độ methanol trong máu cao. Đa số các bệnh nhân của chúng tôi vào viện muộn khi mà methanol đã và đang được chuyển hóa, và các sản phẩm chuyển hóa là acid formic gây tình trạng toan chuyển hóa nặng, tăng KT anion, vì vậy $\mathrm{pH}$ máu giảm thấp. Thông thường, sản phẩm chuyển hóa cuối cùng 
của methanol là acid formic, gây toan chuyển hóa và tăng khoảng trống anion, lượng acid formic càng nhiều thì $\mathrm{KT}$ anion càng cao, đến viện càng muộn thì methanol chuyển hóa thành acid formic càng nhiều $K T$ anion càng tăng. Bệnh nhân vào có cả ALTT, KT ALTT, KT anion cao, có thể suy đoán nếu bệnh nhân vào sớm hơn thì nồng độ methanol máu đo được sẽ còn cao hơn. Tăng ALTT, KT ALTT, KT anion đều gặp ở các nghiên cứu [2], [8].

Kết quả xét nghiệm CK trong nghiên cứu của chúng tôi là 985,5 U/l, ở nhóm tử vong cao hơn nhóm sống $(p<0,05)$. CK tăng cao ở BN có co giật gây tình trạng tiêu cơ vân cấp, vì vậy cần phải xử trí sớm và tích cực tránh suy thận cấp do tiêu cơ vân.

Kết quả xét nghiệm glucose máu trung bình của chúng tôi là $12,4 \pm 6,15 \mathrm{mmol} / \mathrm{l}(4,3-27,7)$, với tỉ lệ $\mathrm{BN}$ có tăng glucose máu là $83 \mathrm{BN}$ (77,6\%). Trong một số nghiên cứu, các tác giả cũng có kết quả tương tự. Tác giả Sanaei-Zadeh $\mathrm{H}$ đưa ra nhận xét glucose máu tăng là yếu tố tiên lượng xấu ở BN ngộ độc methanol [5].

Khi đánh giá về tổn thương thần kinh trong ngộ độc methanol, chúng tôi có $71 B N(66,4 \%)$ được chụp CT/MRI so não. Một số BN do tình trạng bệnh nặng không thể đi chụp so được. Có một tỉ lệ cao, 45BN $(63,38 \%)$ thấy tổn thương thần kinh trên phim $\mathrm{CT} / \mathrm{MRI}$ sọ, trong đó giảm tỉ trọng nhân xám thần kinh trung ương hai bên là $30 \mathrm{BN}(42,3 \%)$, xuất huyết nhân bèo và tổn thương chất trắng dưới vỏ đều là $6 \mathrm{BN}(8,5 \%)$, phù não $3 \mathrm{BN}(4,2 \%)$. Kết quả vị trí tổn thương của chúng tôi phù hợp với Barceloux là tổn thương xuất huyết não có tính chất đối xứng hoặc hoại tử nhân bèo sẫm hai bên [2]. Nghiên cứu của Sefidbakht chuyên về đánh giá tổn thương não qua phim chụp CT/MRI trong ngô độc methanol thấy ngoài xuất huyết não và hoại tử tại vị trí nhân bèo còn gặp thoái hóa chất trắng hai bên và xuất huyết dưới nhện [6].

Chúng tôi có $70 / 107$ BN $(65,4 \%)$ được khám mắt và soi đáy mắt, $37 \mathrm{BN}(34,6 \%)$ không được khám do $\mathrm{BN}$ nặng và nằm viện quá ngắn chưa kịp khám. Chúng tôi thây có 44/70 BN (62,9\%) có tổn thương mắt, trong đó tổn thương thị thần kinh gặp nhiều nhất 26BN $(37,2 \%)$; phù gai thị 15BN (21,42\%); xuất huyết võng mạc $3 \mathrm{BN}$ $(4,3 \%)$. Sau khi ra viện có 16 BN (22,9\%) giảm thị lực, $5 B N(7,1 \%)$ mất thị lực hoàn toàn. Kết quả di chứng mắt trong NC của chúng tôi tương tự của Phạm Như Quỳnh (24,3\%) [1].

\section{KẾT LUÂ̂N}

Bệnh nhân nam là chủ yếu $(97,2 \%)$, tuổi trung

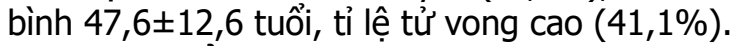

Đặc điểm lâm sàng: đau đâu và nhìn mờ gặp nhiều nhất $(94,4 \%)$, hôn mê sâu $(63,6 \%)$, giãn đồng tử $(61,7 \%)$, mất phản xạ ánh sáng $(45,8 \%)$, suy hô hấp $(79,4 \%)$, suy thận cấp $(54,2 \%)$, tụt huyết áp $(31,8 \%)$, co giật gặp ít nhất $(6,5 \%)$. Nhóm $B N$ tử vong gặp ở tỉ lệ cao hơn nhóm sống về: hôn mê sâu, đồng tử giãn, mất phản xạ ánh sáng, co giật, suy hô hấp, suy thận cấp và tựt huyết áp $(p<0,05-p<0,01)$.

Đặc điểm cận lâm sàng: Toan chuyển hóa năng, ALTT cao, KT ALTT, KT anion, CK, lactat, đường máu đều cao, các chỉ số của nhóm tử vong đều cao hơn nhóm sống $(p<0,05-p<0,01)$. Nồng độ methanol máu cao $157,1 \pm 90,06 \mathrm{mg} / \mathrm{dL}$, nhóm tử vong cao hơn nhóm sống; $p<0,01$. Tổn thương tổn thương thần kinh trên $\mathrm{CT} / \mathrm{MRI}$ sọ $63,4 \%$ (giảm tỷ trọng nhân bèo $42,3 \%$, xuất huyết não nhân bèo $8,5 \%$, tổn thương chất trắng dưới vỏ $8,5 \%$, phù não $4,23 \%$ ). Tổn thương mắt $62,9 \%$ (tổn thương thị thân kinh 37,2\%; phù gai thị $21,4 \%$; xuất huyết võng mạc 4,3\%).

\section{TÀI LIÊU THAM KHẢO}

1. Phạm Như Quỳnh, Lê Đình Tùng, Hà Trân Hứng (2017). Hiêu quả của thẩm tách máu kéo dài trong điêu trị bệnh nhân ngộ độc cấp methanol. Tạp chí Sinh lý học Việt Nam, 21(3), 13-20.

2. Barceloux D.G, et al. (2002). American Academy of Clinical Toxicology practice guidelines on the treatment of methanol poisoning. J Toxicol Clin Toxicol, 40(4), 415-46.

3. Chang S.T., Wang Y.T., Hou Y.C., et al (2019). Acute kidney injury and the risk of mortality in patients with methanol intoxication. BMC Nephrol 20: 205.

4. Lee C.Y., Chang E.K., Lin J.L., et al (2014). Risk factors for mortality in Asian Taiwanese patients with methanol poisoning. Ther Clin Risk Manag, 10, 61-7.

5. Sanaei-Zadeh H., Esfeh S.K., Zamani N., et al (2011). Hyperglycemia is a strong prognostic factor of lethality in methanol poisoning. J Med Toxicol, 7(3), 189-94.

6. Sefidbakht S., Rasekhi A.R., Kamali K., et al (2007). Methanol poisoning: acute $M R$ and CT findings in nine patients, Neuroradiology. 49(5), 427-35.

7. Wedge M.K., Natarajan S., Johanson $C_{\text {., }}$ et al (2012). The safety of ethanol infusions for the treatment of methanol or ethylene glycol intoxication: an observational study. CJEM; 14(5):283-9

8. Zakharov S., Nurieva O., Kotikova K., et al (2017). Positive serum ethanol concentration on admission to hospital as the factor predictive of treatment outcome in acute methanol poisoning. Monatsh Chem, 148(3):409-419. 